University of Nebraska - Lincoln

DigitalCommons@University of Nebraska - Lincoln

To Improve the Academy

Professional and Organizational Development Network in Higher Education

1995

Family Portrait: Impressions of a Nurturing Organization

Jon Travis

Lisa Cohen

Dan Hursh

Barbara Lounsberry

Follow this and additional works at: https://digitalcommons.unl.edu/podimproveacad

Part of the Higher Education Administration Commons

Travis, Jon; Cohen, Lisa; Hursh, Dan; and Lounsberry, Barbara, "Family Portrait: Impressions of a Nurturing Organization" (1995). To Improve the Academy. 348.

https://digitalcommons.unl.edu/podimproveacad/348

This Article is brought to you for free and open access by the Professional and Organizational Development Network in Higher Education at DigitalCommons@University of Nebraska - Lincoln. It has been accepted for inclusion in To Improve the Academy by an authorized administrator of DigitalCommons@University of Nebraska - Lincoln. 


\section{Family Portrait: Impressions of a Nurturing Organization}

\section{Jon Travis}

East Texas State University

\section{Lisa Cohen}

Thomas Jefferson University

\section{Dan Hursh}

West Virginia University

\section{Barbara Lounsberry}

University of Northern Iowa

National conferences and conventions are intended to provide individual development and multiple opportunities to share. The POD Conference offers yet another important feature not common to national educational organizations, instant affiliation.

\section{Family Portrait: Impressions of a Nurturing Organization}

Each of us became members of a new family (new to us at least) last October. Because of the extraordinary impact on us by this group and its national conference, a report of our reaction seemed to be in order. Hence, we offer our collection of impressions, a portrait in words.

No doubt, the majority of educators maintain membership in at least one professional organization, even attending the group's conferences, be they local, regional, or national. Such gatherings com- 
monly exhibit vigorous networking of long-standing informal groups that are clearly "inside operations" within the particular organization. The various alliances and rivalries engendered by professional organizations and their familiar appendage, the conference are not unlike those represented in Lodge's Small World (1984). However, the "small world" of the conference is generally a private club. Novice attendees are usually not immediately welcomed into the specific informal groups. Hence, newcomers are casually left alone as outsiders-left to their own devices to work their way into a group.

Why should an organization's new members have to attend several annual meetings to begin finally to feel any sense of inclusion? The Professional and Organizational Development Network in Higher Education (POD) is clearly not the typical professional organization described above. Accordingly, one may conclude that POD conferences are also atypical. Happily, this is the case.

A number of distinguishing features set POD and its conferences apart from the professional organizations and meetings one may regularly encounter. First of all, the POD vision attempts to be both comprehensive and systematic. POD refuses to see development narrowly; rather, it works constantly to remind membership that faculty development can lead to instructional development (or vice versa) and that both have roles to play in optimal organizational development. This systemic vision provides a rich theoretical context for everything POD does.

All organizations are distinguished by their individual members (Argyris, 1964; Barnard, 1968). From the initial exposure one has to the POD organization, the people who make up its membership appear especially distinctive. First of all, the organization appears to be promoted chiefly through individual contact. Each of us was drawn into the organization through the encouragement of one or more POD members. The operant word in the organization's name, therefore, is definitely "network."

The members of POD demonstrate their effective people skills in other ways as well. We were all impressed with the friendliness of the membership. Being openly drawn into conversation, in workshops as well as in social gatherings, while commonplace at the POD conference, is a rare experience at many other organizations' events. The 
willingness of POD members to share information is yet another conference benefit, one that caught some of us off-guard, albeit pleasantly. Strangers, like ourselves, were warmed by the generosity of spirit so apparent at the POD conference. In POD, egos are low and sharing high. In fact, POD seems to pride itself on its permissive approach to research and materials: if it is useful, use it, seems to be the POD way-although members scrupulously acknowledge their intellectual debts. Obviously, the concept of a network remains dominant throughout the organization.

An example of the lack of pretentiousness prevalent at POD conferences is the direct access we had to the conference chair, organization president, and other group leaders. One of us attempted to visit with the president of another national group at an annual conference only to be rebuffed with a strong non-verbal message: "I'm too busy." Also, the POD conference is routinely attended by significant authors in the fields of faculty development, teaching, and instructional leadership; journal editors; and publishers, all of whom are likewise readily accessible. Mutual respect, akin to Native American spiritual tenets, abounds. We experienced a genuine concern for one another and our combined mission to improve education.

The organization of the POD conference and substance of the individual sessions are another asset. POD conferences routinely experiment with new presentation formats. A sense of humor accompanies this exercise in experimentation, which can make for quite a heady atmosphere. In addition, conference sites of unparalleled natural beauty are selected to remind us that the world is not found entirely in a meeting room.

The conference began with a workshop for those new to faculty development, immediately providing a wealth of useful information. As with any organization, this process of orientation is so much more successful if new members are provided with an opportunity to establish a support group among themselves. This session easily afforded all of us the means to form such a group, even given the circumstance that the new member group included people from a range of higher education settings. The leaders of the workshop made sure that we knew who was from which kinds of settings to make it easier for us to identify who we might want to contact later. The 
organization clearly wanted to ensure that every opportunity was created for us to begin to be a part of the network.

The conference offered a mix of presentations, discussions, workshops, and case studies that were most helpful in establishing a continuous array of worthwhile sessions. Often the problem was to determine which of two or three sessions to select. The concurrent sessions also demonstrated that POD practices what it preaches. Members know what makes for good teaching and exemplify it in their presentations. No talking heads appeared in the concurrent sessions. In fact, presenters apologized profusely when their sessions involved more lecture than interactive learning.

POD presentations were always active, and were often collaborative and included multi-media. Handouts were also plentiful. Indeed, presenters often gave us our basic notes at the outset - so we made no mistakes on key concepts and definitions. This freed us to move from simple comprehension to forms of synthesis and application. Participants thereby tend to learn much more, more quickly, at a POD conference session.

At many sessions we found participants with similar interests, which led to animated conversations and more networking. Breaks provided many opportunities for these conversations and were always enhanced with food and drink. In no other conference we attend is care taken so consistently for the experience of the audience. Even the meals were designed to keep the occasions for networking going. One very common maxim in faculty development, which was frequently confirmed for us throughout the conference, is that any activity that incorporates food attracts more participants and occasions more active involvement. The location of the conference hotel and inclusion of food costs in the room rates helped to ensure that we spent most of our waking hours together in one activity or another.

In conjunction with the notion of sharing among the membership and adding to the remarkable conference atmosphere, the affective domain was not neglected. Any professional conference must address the need for intellectual fulfillment. However, for educators, especially faculty developers, the affective domain is our "engine." Educators do a great deal of nurturing in their profession. To presume that educators do not themselves need a nurturing experience is unwise. 
Unfortunately, too many professional organizations conduct annual conferences that could be mistaken for a row of loaded boxcars racing down the tracks toward oblivion.

Throughout the POD conference, a calculated regard for the affective needs of individuals permeated each event. Deliberate mixing of groups was included in the program to avoid the trap of cliquishness. The whole conference atmosphere resembled a holiday gathering of a large family -though without the histrionic games (Berne, 1964) of a typical soap opera script. Honest emotions and a manifest effort for inclusion prevailed. Everyone at the conference seemed to go out of their way to make us feel comfortable.Another new member of the group, who had been commissioned by the conference chair to perform for those assembled, demonstrated a physical metaphor which so characterizes everyone in POD: outstretched arms in an overt display of openness and welcome. Not long afterward, many members were mimicking this gesture of joy. If the group needs a physical symbol of its character, this one would certainly be appropriate.

In summary, the POD conference was so unusual that it remains vibrant in our memories, unlike the familiar "cut flower" programs, mentioned by yet another new member. Understandably, these glowing observations are based solely upon the experiences of a few participants at one conference, clearly insufficient for statistical significance. However, a reasonable effort on our part to confirm these findings supports the conclusion that future POD conferences will continue the success story. To those within the POD Network, this is our statement of thanks. To everyone else, this is what you have been missing.

\section{References}

Argyris, C. (1964). Integrating the individual and the organization. New York: John Wiley. Barnard, C. I. (1968). The functions of the executive. Cambridge, MA: Harvard University Press.

Berne, E. (1964). Games people play: The psychology of human relationships. New York: Grove.

Lodge, D. (1984). Small world: An academic romance. New York: Macmillan. 